\title{
Indonesia's Economic Growth from 2019 -2021: An Economic Overview Before and During COVID 19 Pandemic
}

\author{
Wiwin Priana ${ }^{1}$, Dewi Khrisna Sawitri ${ }^{2 *}$ \\ ${ }^{1}$ Department of Economic Development, Faculty of Economics and Business, Universitas Pembangunan Nasional \\ "Veteran" Jawa Timur, Surabaya 60294, Indonesia \\ 2Department of Management, Faculty of Economics and Business, Universitas Pembangunan Nasional "Veteran" \\ Jawa Timur, Surabaya 60294, Indonesia
}

${ }^{*}$ Corresponding author:
E-mail:
dewikhrisna.mnj@upnjatim.ac.id

\begin{abstract}
Almost all countries suffer from The Covid 19 pandemic which has emerged since late 2019. This pandemic has greatly impacted the nation's economic growth. Indonesia is also one of many nations with high cases of COVID 19 victims which have experienced the decline of economic growth. Economic growth is also a measure of the economic performance of a nation's community, the more productive the people in that nation than the higher the economic growth of the nation will be. Economic growth will be obtained from the increase of GDP from year to year. This study has an objective to analyze economic growth in Indonesia which happened before COVID 19 in 2019 until the year 2021 in which this pandemic has still given its economic impact on the nation. Indonesia's economic growth in 2019 was $5.03 \%$, in 2020 was $-2.20 \%$ and in 2021 the $2^{\text {nd }}$ Quarter has reached $7.07 \%$. The research method is conducted by analyzing the Report of GDP and Economic growth released by the Central Statistics Agency (BPS). The sample of this research is the year 2019, 2020, and 2021.
\end{abstract}

Keywords: Economic growth, COVID 19 Pandemic

\section{Introduction}

According to Zhang et al. (2021), mentioned that almost all nations in all the world were rushed because of this COVID 19 Pandemic which has caused 0.19 billion victims to be reported and led to almost 4.1 million people dying. Somehow, this pandemic still happens and the effect has struck not only society but also economics for years (WHO, 2020c). The coronavirus, at first, was found for not giving heavy impact in which resulted in slight infections for body immunity. Consequently, this was also considered not to be pathogenic for humans as they spread in Guangdong China in which came up and mentioned as SARS, Severe Acute Respiratory Syndrome. The coronavirus came up in another version in 2012 and 2013 in which people called it MERS, Middle East Respiratory Syndrome (Inegbedion, 2021). The present form of coronavirus mentioned as COVID 19 was related to the latest virus which is known as SARS-CoV-2 in which firstly emerged in China year 2019 (Zhu et al., 2020). WHO mentioned that on $14^{\text {th }}$ May 2020, for more than 5 million reported cases regarding COVID-19 in which separated in some different continents around the world for about 1,030,738 fatalities globally from Africa, South East Asia, America, Europe, and Western Pacific (WHO, 2020a;2020b). This pandemic still last and undoubtedly can cause impacts in many aspects of human life.

The COVID 19 Pandemic has interrelated with the economy situation which has also emerged in richer countries as high incidents confirmed and countries with higher incidents would cause more 
decrease of GDP per capita (GDPC) in 2020 (Zhang et al., 2021). With the increase of COVID 19 cases, the economic growth in many countries around the world has penetrated deeper. The value of international commodities generally has decreased with the decrease of global demand, as mentioned that the price of world crude oil was informed negative in April 2020 because there was a high supply from supply vessels.

Indonesia is also one of many nations all around the world that is still struggling to recover from this economic impact caused by this pandemic. The policy in implementing social distance has raised some economic struggle for a society in the majority as the economic growth decreased to some lowest point in 2020. This year was considered difficult for Indonesia. The next phase has opened a warm welcome in which the social distance policy was being untied. This has made a slight growth in the year 2020. Surprisingly, the price of the commodity has raised and caused the growth to increase in the second three months phase for 5,32. Meanwhile, some sectors could contribute to give positive growth i.e. agriculture, communication technology, real estate, health, education, and finance. Indonesia's Government has implemented many programs which consequently affect its citizen how to social interactions and of course, this also affects the way its people economically act. Lately, PPKM, this is how the term is given that deals a lot in limiting human interaction in working is conducting during August 2021 This policy also gives tremendous impact to many sectors i.e. education, business, financial and banking manufacture, and many more. As Indonesia has experienced this pandemic since 2019 so this study try to elaborate how the timeline of the COVID 19 pandemic gives impact to Indonesia's Economic growth from the year 2019 until 2021, this present time

\section{Material and Methods}

This research is a qualitative method by analyzing scientific literature review and data given by Central Statistic Agency. This study conducts multidisciplinary analysis not only from the health side but by understanding the phenomena that happened in the society analyzing the economic growth can also give a further point of view on how the pandemic gives impact to the national economy. The rate of economic growth in Indonesia was presented from the year 2019 until the year 2021 during this COVID 19 pandemic. By analyzing the secondary data of economic growth, researchers try to elaborate how this growth reflects the economic condition before and during the pandemic happens. The data, which was presented every three months, can give a complete outlook on how the nation's growth in economy fluctuated.

\section{Results and Discussion}

The Prediction of the International Labor Organization mentioned that COVID 19 pandemic will cause a decrease in revenue for about $60 \%$ in informal jobs and survival is done by all nations without implementation of any kind of social protection (Zhang, 2021). It is not surprising to know that pandemics can cause a fluctuation in a nation's economic growth. Data mentioned by the BPS has shown significant differences in economic growth before the pandemic happened and during this pandemic. 


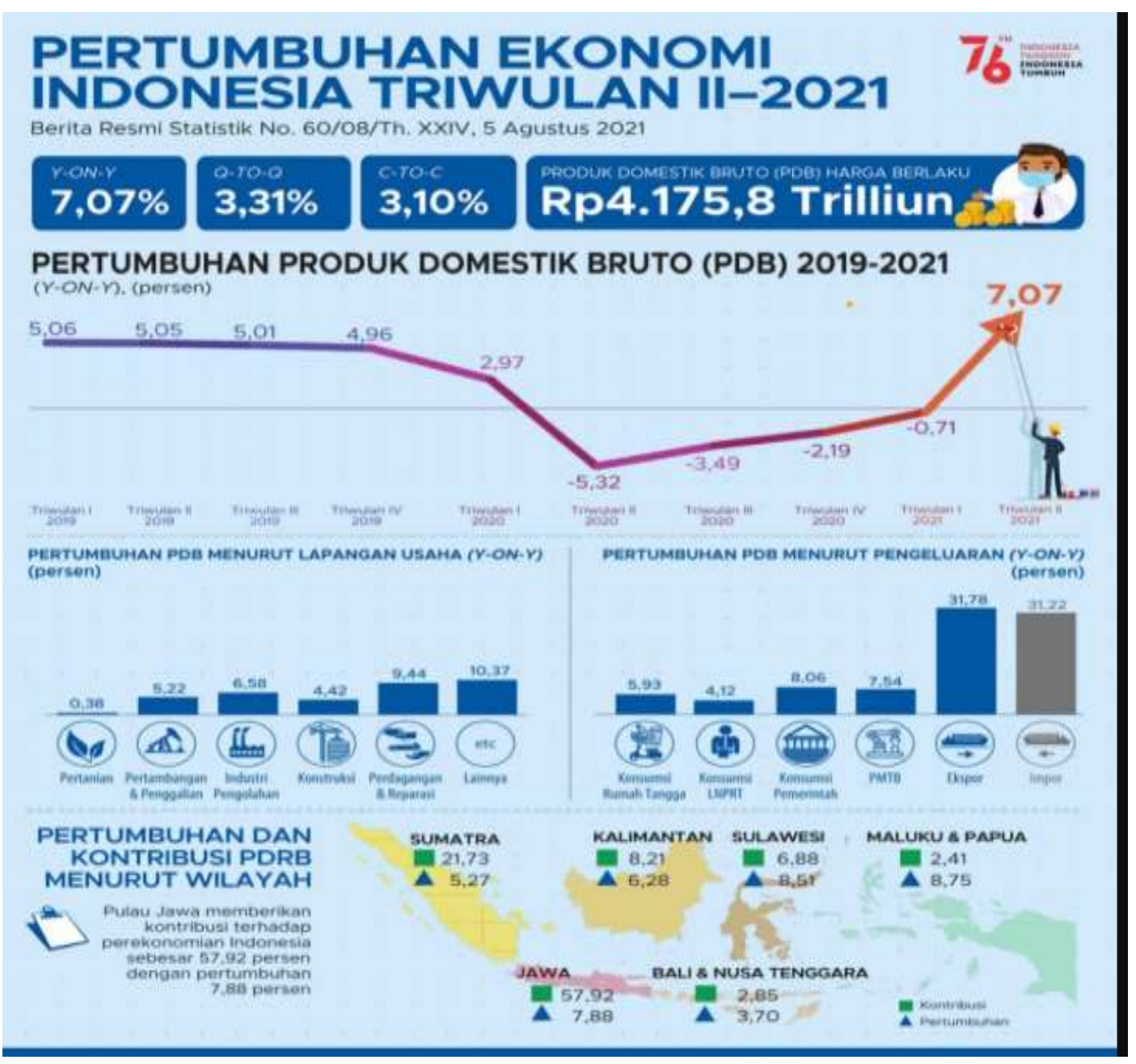

Figure 1. Indonesian Economy Quarter II 2021 (Source: BPS, 2021)

The BPS Data has shown that before COVID 19 stroke Indonesia, the economic growth in 2019 was considered high reached at 5,03 but a great difference happened when it firstly hit which cause the growth to decrease to $-2,97$ and finally hit its lowest rate at-5,32. The next two Quarters in 2021 have shown that Indonesia can crawl up and reach $-0,71$ at the $1^{\text {st }}$ Quarter and 7,07 at the $2^{\text {nd }}$ Quarter. By then Indonesia has returned to its positive zone after suffering from an economic recession for a few three months, impacted by this pandemic. This performance is considered low for the last 17 years in Indonesia. Compared to other nations, this economic growth is considered high, i.e. India which only reached 1.6 for its $2^{\text {nd }}$ Quarter in 2021 meanwhile South Korea only 5,69 and Japanese -1,6. The Indonesia Government mentioned this growth as a success of strategy implemented in some sectors. This realization is almost suitable with the prediction of the Minister of Finance which predicts the growth at 7.1. The strategy has shown its recovery and results positively.

The strategy which is considered a success in elevating economic growth is Social Support which can maintain the poverty level and household consumption for the low level of society. This social support was given by the central and regional government, this was able to maintain the poverty level for not increasing highly. The increase of economic growth is also shown by the society that is beginning to start consumption activity. It is noted that online buying contributes to the increase in consumption. However, Indonesia is a country that still implements protective social policy for its citizen. PPKM, which is known as a program that limits human activity in working, is implemented rigidly as the regulation is conducted in Java and Bali island. Some of the policy rules mentioned are: 
- The teaching activity (school, higher education institution, training, etc) is conducted online

- The non-essential sector is $100 \%$ conducted remote from home

- The essential sector can operate a maximum of $50 \%$ for public service and $25 \%$ for office administration

- Traditional markets, supermarkets, and groceries which sell daily needs can operate in some limited time for a maximum of $8.00 \mathrm{pm}$

- Pharmacy is allowed to operate for 24 hours

- Food vendors, laundry, and other small businesses can open with a tight health protocol

Government policy is believed to contribute to how the society will perform its economic society. Based on the data shown by the BPS, it is also noticed that Java island contributes to national economic growth for 57,92 with the rate of growth hitting at 7,88 . Meanwhile, another region which is Sumatra contributes about $21,73 \%$ with a rate of growth reaching 5,27 . This shows how the policy implemented in Java can still support the economic activity so some sectors economically can still perform and contribute to Gross Regional Domestic Product.

\section{Conclusion}

It is noticeable that Government plays a significant role in elevating its economic growth. COVID 19 Pandemic, which happens not only in Indonesia but also in many other countries, has shown how it can strike human life, not in the health sector but it mostly hit the economy sector. Socially, the decrease of economic growth can give a reflection of a nation in explaining how its citizen struggles to survive from poverty in which the consumption was performed at a low point. As mentioned by The World bank (2021) that during this pandemic, it was witnessed that more than 120 million people lived with an income of less than $\$ 1,90$ per day. Many people lost their job so this recovery is also a fight for crucial poverty globally. America has also witnessed approximately 20 million jobs lost experienced by its citizen which happened during this COVID 19 from January to April 2020 (Coibion et al., 2020)

\section{References}

BPS. (2021). Ekonomi Indonesia Triwulan II 2021 tumbuh 7,07 persen (y-on-y). Retrieved arthttps://www.bps.go.id/pressrelease/2021/08/05/1813/ekonomi-indonesia-triwulan-ii-2021-tumbuh-7-07-persen--y-on-y-.html

Coibion, O., Gorodnichenko, Y., \& Weber, M. (2020). Labor Markets During the COVID-19 Crisis: a Preliminary View (No. w27017). National Bureau of Economic Research. doi: 10.3386/w27017

Inegbedion, H. (2021). Impact of COVID-19 on economic growth in Nigeria: opinions and attitudes. Pacific-Basin Finance Journal, 68(2021), 101597. doi: 10.1016/j.heliyon.2021.e06943

WHO. (2020a). Coronavirus disease (COVID-19). https://www.who.int/docs/default-source/ coronaviruse/situation-reports/20201005weekly-epi-update-8.pdf.

WHO. (2020b). Coronavirus disease (COVID-19). https://www.who.int/docs/default-source/ coronaviruse/

WHO. (2020c). Coronavirus disease (COVID-19) pandemic. 2020, https://www.who.int/emergencies/diseases/novel-coronavirus-2019 World Bank. (2021). Global economic prospects: January 2021. Washington, D.C: The World Bank.

Zhang, Z., Kong, L., Lin, H., \& Zhu, G. (2021). Modeling coupling dynamics between the transmission, intervention of COVID-19 and economic development. Results in Physics, 28 (2021), 104632. https://doi.org/10.1016/j.rinp.2021.104632

Zhu, N., Zhang, D., Wang, W., Li, X., Yang, B., et al. (2020). A novel coronavirus from patients with pneumonia in China, 2019. N. Engl. J. Med. 382, 727-733. Doi: 10.1056/NEJMoa2001017 